\title{
Forced eviction and rights-based approach to development in Nigeria: A case of Makoko community in Lagos State Olumuyiwa Ajayi ${ }^{1}$ \& Peyibomi Soyinka-Airewele ${ }^{2}$
}

\author{
${ }^{1}$ Department of Political Science and International Relations, Covenant University, \\ Ota, Nigeria \\ ${ }^{2}$ Department of Politics, Ithaca College, New York, United States of America \\ Email: muyiwa.ajayi@covenantuniversity.edu.ng
}

\begin{abstract}
Background: The problems created by forced evictions in Lagos State, Nigeria and other parts of the globe, are on the increase and have attracted the attention of United Nations development, environment and human rights agencies in recent years.

Data Source and Methods: A cross-sectional field survey was adopted in this study. 1000 copies of questionnaire were administered, and 963 copies were properly filled, collated and analysed using Statgraphics statistical software and Statistical Package for Social Sciences (SPSS 23).

Results: The survey results show that rather than resolving the problem, the Lagos State government's approach to development by eviction only worsens the social divides in the state.

Conclusion: We argue that the Lagos State government needs to embrace a rights-based approach to development by ensuring the rights to occupancy of Makoko residents before renovating the settlement
\end{abstract}

Keywords: Forced eviction, Lagos, Makoko, Policy actions, Rights-based approach to development.

\section{Introduction}

The task of developing slum communities in Nigeria's Lagos State is enormous and challenging. Makoko the study area of this study, is a prominent informal slum settlement with a long history as a distinctive waterfront indigenous community. Unfortunately, it faces the type of crisis that scholars depict as a "wicked problem" which requires a holistic and multi-faceted approach to overcome (Hoelzel, 2016; Chapman and Maki, 2016; Fung, 2015; Nwanna, 2015; Folarin, 2010). There are multiple ways to achieve sustainable urban development and this requires a rigorous planning process that involves several stakeholders. The problems created by forced evictions in Lagos State, Nigeria and other parts of the globe, are on the increase and have attracted the attention of United Nations development, environment and human rights agencies in recent years. The United Nations now considers the forcible eviction of residents from their places of abode as a gross violation of human rights (Folarin, 2010). The recent declarations by the current Lagos State government only reasserts their resolve to forcibly take such waterfront communities from the indigenous occupants and newer residents without any regard for their fundamental human rights as vulnerable people (Ajayi, Soyinka-Airewele and Samuel, 2019; Falayi, 2017).

This approach is in violation of international human rights laws. The intentions of the government are not lucid, as it has failed to clearly state its future plans for those who were displaced in 2012 and those who will be affected should any demolition exercise occur again in Makoko area of Lagos State. This should remind us of previous forced evictions in Maroko in 1990 under the leadership of Lagos Governor, Col. Raji Rasaki, which saw over 300,000 people displaced; and most recently the Otodo Gbame debacle at Lekki in April, 2017, which saw thousands of people forcibly evicted and displaced in a gruesome manner (Falayi, 2017). This study highlights the need for a rights based approach to development in Makoko, Lagos State by carefully highlighting the true nature of the consequences of forced eviction on people living in Makoko area of Lagos State, Nigeria.

The problems associated with forced evictions, repercussions and emergent development challenges are illustrated in the figure below. 


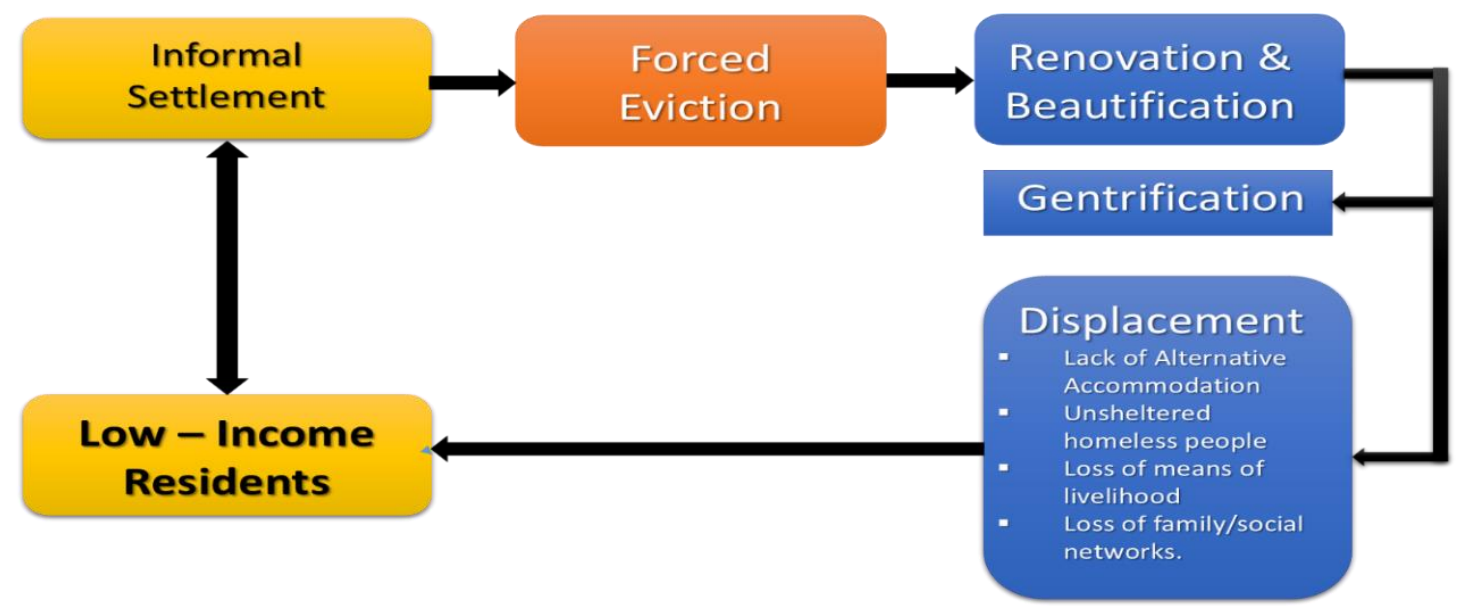

Fig. I: Problems Associated with Forced Evictions and Displacement in Makoko Area of Lagos

State, Nigeria

Source: Ajayi, 2019

The social and economic features of Makoko residents, their quality of life and environmental situation show that they are incapacitated and have little or no power to alleviate their present situation. Some of the challenges they face include overcrowding, poor housing; lack of security of life, property and tenure; constant outbreak of diseases; environmental hazards; lack of basic infrastructure; social exclusion and crippling poverty. Incidentally, the Lagos State government has not been able to provide basic facilities to cope with the growing population of the community. Both governance and policy responses have not been able to meet the challenges of Makoko community to achieve sustainable urban development that is people-centred (Chapman and Maki, 20I6; Nwanna, 20I5; Folarin, 20I0).

It is practically difficult for Makoko residents to have access to land and housing, which explains why they sought refuge in Makoko area, where they coud buy land and build their houses, mostly on stilt, according to their means and ability. While they typically lack protection of tenure because they do not have certificate of occupancy, many residents of Makoko have bona fide rights and privileges in the land on which they live, having acquired those lands from legitimate land owning families and communities (Ajayi, 2019; Chapman and Maki, 2016; Morka, 2007).

In order to critically assess the problem of renovations in Makoko community and investigate the perceptions of the residents about the Lagos State's policy for development, the following research propositions were put forward:

a. The Lagos State government's policy of development is oriented toward beautification and gentrification, rather than the welfare of slum dwellers. b. The existing development policies in Lagos State will intensify the socio-economic insecurity of current Makoko settlers and worsen social inequalities in the State.

c. Despite official claims of the merits of renovating the settlement, Makoko residents are likely to have negative responses to gentrification and oppose the government's plans for renovations of the Makoko settlement.

\section{Literature review and theoretical framework}

The globe has become more and more urbanized in the $21^{\text {st }}$ century, with the bulk of the global population living in cities and towns. In developing countries, where citizens' wages are at the lowest, the highest rates of urbanization are now taking place. This indicates that poverty, which used to be a rural phenomenon, is increasingly becoming an urban problem, especially in the developing world. Current data suggest that urban areas are the key drivers of economic prosperity and they also in the strongest position to contribute to poverty eradication.

At the inauguration of the Sustainable Development Goals (SDG) agenda, the United Nations clearly highlighted the fact that over I billion people live in slums today and the number keeps rising on a daily basis (United Nations, 2018; United Nations, 20I5; Weiss, 200I).

In the sense that cities are locations of modernization and attractors of industrious and agile individuals, urbanization is an impetus for growth and wealth formation. The potentials of urbanization in developing countries, however has been hindered by its overwhelming negative effects, such as congestion, environmental pollution, unemployment, poverty and the emergence of slums, often as a result of the inability of the government to adequately meet the need for housing and basic infrastructure of those at the lowest rung of the societal ladder (United Nations, 2015; Serageldin, 1996). 
Furthermore, the urban poor have to confront additional layers of political corruption, police brutality, identity tensions and violence, from a position of marginalization and lack of meaningful political participation and representation (SoyinkaAirewele and Edozie, 2010:15).

Several years after the opening of the Rio Conference to tackle the key environmental and sustainable development problems, environmental and sustainable development challenges remain evident globally. The exponential population growth and the rapid pace of urbanization have created major problems that are connected with nonaccommodation, overcrowding, insufficient infrastructure and basic services in most urban settlements globally. Because of these, the most governments enacted the national housing policy and strategies for implementing programmes aimed at promoting sustainable human settlement development (United Nations, 2018; UN-Habitat, 2016).

Although 'development' is difficult to describe, it is widely accepted that a number of components are involved, such as increased economic growth, equity and distribution of the fruits of that growth, the population's control of its own destiny and the achievement of transcendental qualitative values. In addition, various researches have shown that 'development' cannot be described in purely quantitative terms and varies over both time and space. It is better interpreted in terms of people's desires and values in their own social context, and it is possibly only relevant on a sub-national level in this sense. For many parts of informal settlements in Lagos, most especially in Makoko area, there is no compelling evidence that 'development,' however defined, is taking place. Increasing degradation would be a better description than 'development' for the current trends (Ajayi, Soyinka-Airewele and Samuel, 2019; Hoelzel, 2016; Chapman and Maki, 2016; Fung, 2015; Nwanna, 20I5; Watson, 20I3).

Extensive review of literature reveals that the scholarship on urban development, and housing policy in Nigeria still lacks a clear methodology for engaging the underlying philosophy on how the poor are actually regarded within the parameters of the government's development policy and practices. This study takes up the urgent need to understand why urban development projects repeatedly result in lopsided or uneven landscapes that feature areas of high affluence and extreme poverty. The Nigerian government, like many others, intermittently announces housing projects ostensibly designed to address housing needs for low-income populations. Yet the emergent urban environment tends to become increasingly socially polarized. Such sharp social polarization deepens the crisis of poverty, resistance, social tension and human insecurity within urban locations (Ajayi, 2019).

Development scholars have shown considerable concerns about current patterns of global development in relation to sustainable urban development. These scholars have shown more concern about equity, poverty, exploitation, and the plight of vulnerable groups in developing countries like Nigeria. Most of them are influenced by Marxist, socialist and anarchist critiques of capitalist development. They tend to see traditional forms of development and traditional development agencies themselves as the problem-creators. They frequently view structural inequality and elites' overconsumption as the root causes of unsustainability and would prefer to see current political and economic frameworks overhauled (Ajayi, Soyinka-Airewele and Samuel, 2019; Hoelzel, 2016; Chapman and Maki, 2016; Darrow and Tomas, 2005; Frankovits, 2005; Cornwall and Nyamu-Musembi, 2004; Wheeler, 1996).

Despite the intermittent emergence of some formal low housing settlements, the overall impact of urban planning in the country belies the claim to 'development' when framed in terms of the need for human security and wellbeing. This study aims to fill a gap in the literature on urban planning and development by recognizing that a sustained and effective pro-poor approach to urban planning must systematically engage a framework of human rights, development practice and gentrification (Ajayi, 2019).

This study adopts a rights-based approach theorization of development and the social choice construct as methods for capturing and estimating the apparently wide gap between the accounts and objectives of the Makoko Lagoon dwellers in Lagos State, Nigeria and the real estate developers, development specialists and policymakers who trust their idea of 'development' is the focal mission of a developing country. This approach argues that the poor are rational and make calculated choices designed to enhance their access to economic opportunities, thus they remain in the slums, despite its debilitating poverty for reasons of social and economic choice.

These choices also reflect the deeply stratified sociocultural, class and geographical systems in which they are compelled to live (Soyinka-Airewele and Edozie, 2010:14). While the poor live insecure and vulnerable lives due to government sanctions, they do believe they should have a right to security of housing, of tenure and protection from encroachment as well as right to basic services. They 
are not ignorant as many assume, but aware of government policies and how it might impact them (Ajayi, 2019; Ajayi, Soyinka-Airewele and Samuel, 2019).

It is imperative to note that if the successive administrations and different government partners in Lagos State, Nigeria, embrace a rights-based approach to deal with advancement alongside proper socio-culturally contextualized instruments to ensure equitable housing distribution, there will be huge changes in the settlements that will bring about important economic development, environmental protections and a general improvement in the lives of its residents. Besides, it will diminish the different shades of violence (including physical, psychological, structural and cultural violence), social insecurity and homelessness that have accompanied previous incidences of forcibly evicting the urban poor (Ajayi, 2019; Ajayi, Soyinka-Airewele and Samuel, 2019; Hoelzel, 2016; Folarin, 2010).

\section{Data and methods}

\section{Study design}

A cross-sectional field survey design was employed in this study. Using Bhattacherjee's (20/2) statistics of sampling parameters, 1000 copies of questionnaire were administered. Out of the 1000 copies distributed, 963 of them were properly filled and collated. The research was carried out with the help of two research assistants in order to cover the whole community due to time constraint and they were guided carefully on the process of data collection. The structured questionnaire was administered to residents on face-to-face basis. The selection of respondents for this study followed a cluster sampling procedure, which is a special case of multi-stage sampling. There are three stages identified using this process. In the first stage, streets were selected, considering the fact that Makoko is a ward under Yaba Local Council Development Area (LCDA). Under Makoko Ward, there are 19 welldefined streets and many shanties inside the Lagoon. All the houses in the Lagoon were treated as one street, making it twenty (20) streets. The following were the streets in Makoko area from where the respondents were selected: Ajanlekoko Street, Akibo Street, Raimi Street, Appollo Street, Bale Street, Church Street, Enimakure Street, Erejuwa Street, Falodun Street, Igbehinadun Street, Olaiya Street, Olamide Lapite Street, Olubi Street, Olulu Street, Oluwatoyin Street, Ramotu Lane, Ramotu Street, Sariyu Street Rafiu Street and several houses on the Lagoon (commonly referred to as Makoko "oriomi"). At the second stage, 50 houses were selected from each of the streets. At the third stage, one respondent was selected from each house across 20 streets, to give a total of 1000 respondents.

\section{Study location}

This field study is a part of an unpublished doctoral thesis. The study was conducted in Makoko. Makoko is a slum community originally established in the eighteenth century as a fishing village and its estimated population as of 2006 was 113,740 and 234,420 in 2016. A large part of the area rests on structures constructed on stilts above the Lagos Lagoon. Makoko and its two neighbouring communities, Oko-Agbon and Ago-Egun lay like three mal-nourished triplets, as they appear to have been neglected by the Lagos State government. The three interlocked communities are connected by a short bridge constructed over a wide canal in which there is stagnant, black and murky water. Although the three communities are distinct, they share a common history, characteristics and problems but Lagosians generally refer to the whole area as Makoko area of Lagos State.

Oko-Agbon was first populated by the llaje from Ondo State, while Ago-Egun was first inhabited by the Egun people from Badagry and the Republic of Benin. According to community leaders in the area, the llajes and the Egun first settled at Agege-Odo, the site where the University of Lagos is located today. The Ilaje and the Egun were later evicted by the government in the 60s, when the University of Lagos was to be built (Ajayi, 2019).

\section{Method of analysis}

The data were analysed using descriptive statistics such as frequencies, percentages and graphs from Statgraphics statistical software and the Statistical Package for the Social Sciences (SPSS 23) software. The data were presented with the use of charts and graphs and the survey findings were used to analyse and validate the research propositions.

\section{Ethical considerations}

The researcher obtained all necessary permission from respondents and secured the approval of protocol after full committee review of the Covenant University Health Research Ethics Committee (CHREC/025/20 I8), before conducting this study.

\section{Results \\ Data presentation and analysis}

In Fig. 2, the perceived effect of renovation and transformation of Makoko by the Lagos State Government is presented. The figure shows that the attempt to renovate and transform Makoko would lead to displacement and homelessness $(89.82 \%)$ or relocation $(6.96 \%)$ or loss of means of livelihood 
(3.22\%). This result further confirms that Makoko settlement provides shelter for thousands of the poorest city dwellers in Lagos State.

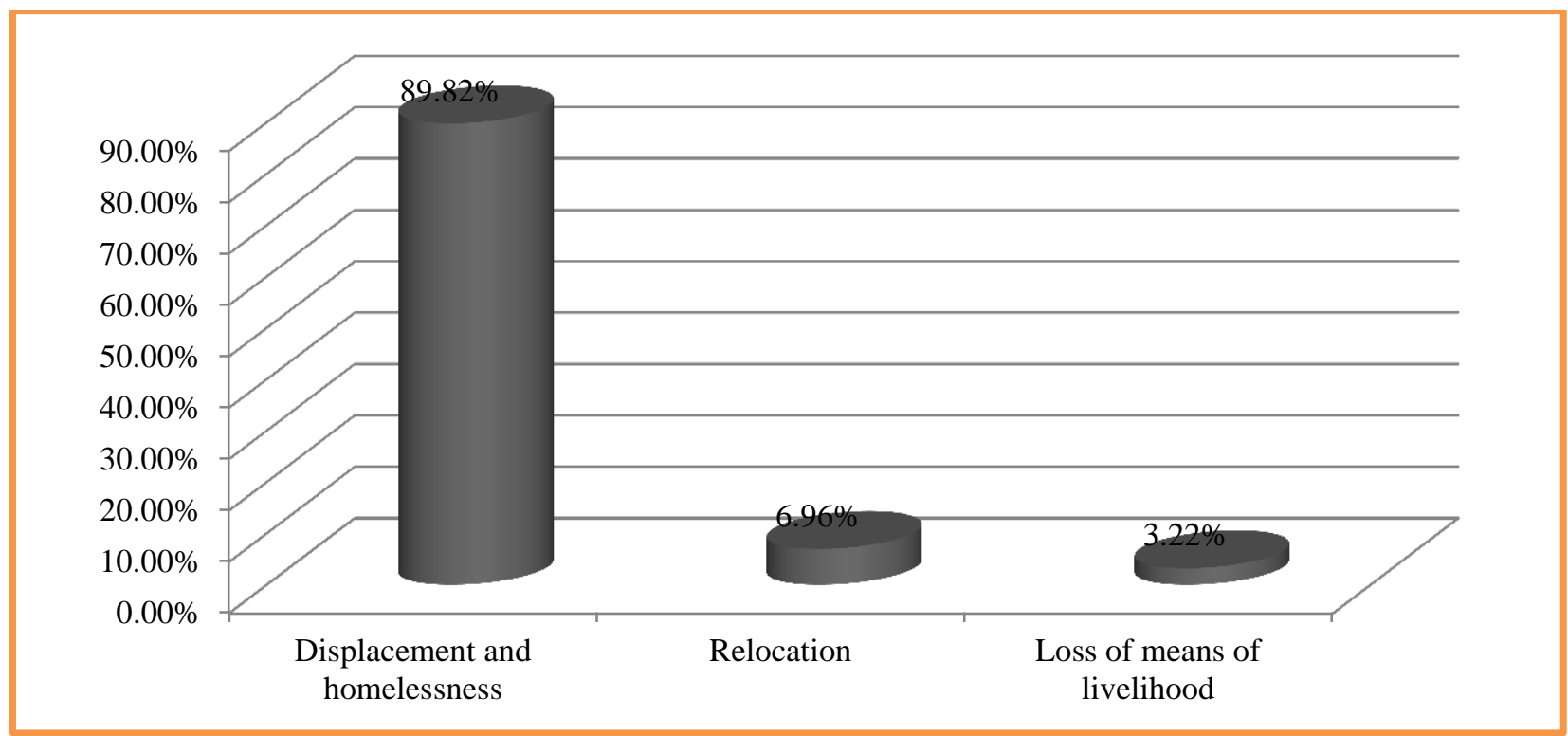

Fig. 2: Field survey showing the perceived effect of renovation and transformation of Makoko on the residents

Source: Authors' Computation, 2018

Fig. 3 clearly shows that majority $(88.8 \%)$ of the people living in Makoko live there mainly for socioeconomic reasons as opposed to just loving the place and other reasons. What is deducible from this finding is that there is a wide gap in the provision of decent and affordable housing in Lagos State, a State with a population growth of about $7 \%$ per annum. Today, empirical evidence shows that Lagos State has the smallest land mass with the highest population in Nigeria.

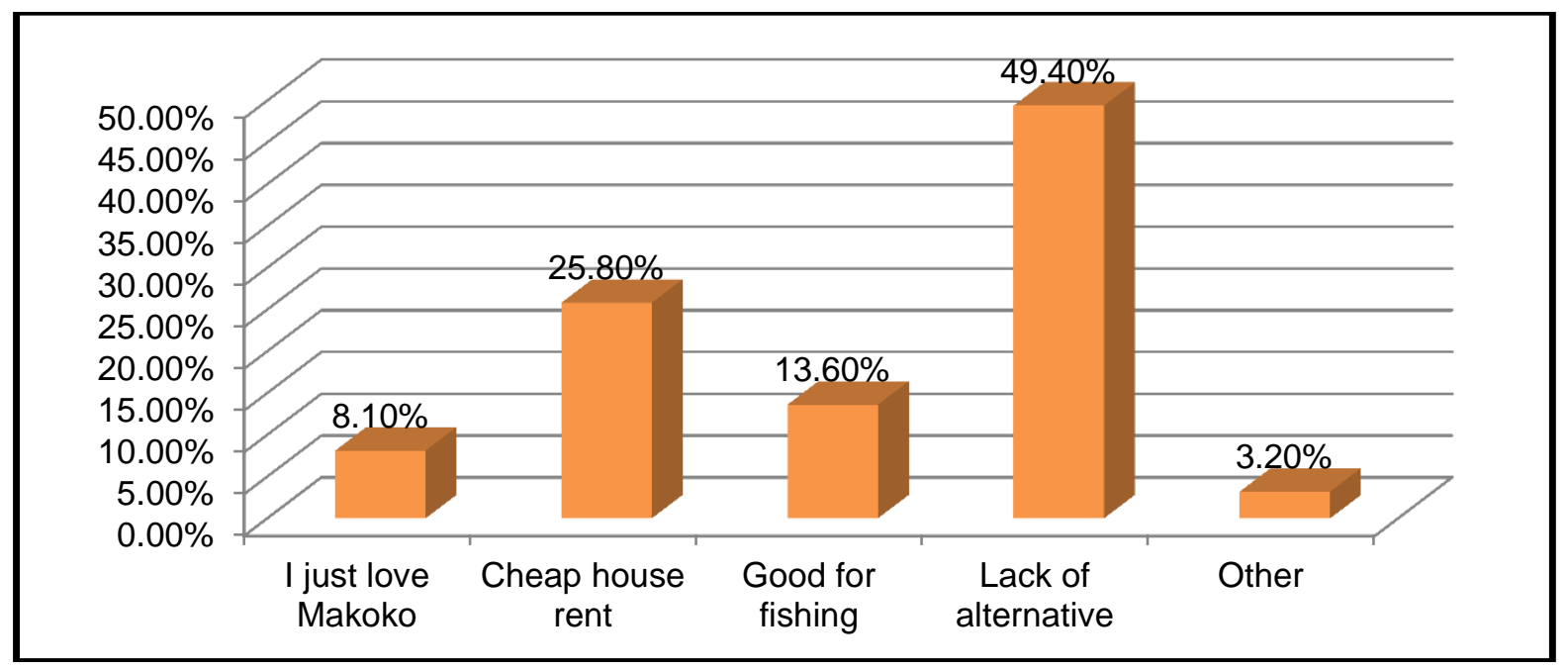

Fig. 3: Field survey showing reason for living in Makoko

Source: Authors' Computation, 2018

In Fig. 4, $83.7 \%$ of the respondents said they were aware of the Lagos State government's plan to renovate and transform Makoko in 2012 through its eviction notice. The remaining $16.3 \%$ said they were not aware. It is important to state that this kind of move by the Lagos State government is not strange to many as it has been witnessed in several other places (Agege, 1973; Ketu, 1976; Bariga, 198I; Maroko, 1990; Makoko, 2005/2010/2012; Otodo Gbame, 2017) within the State. 


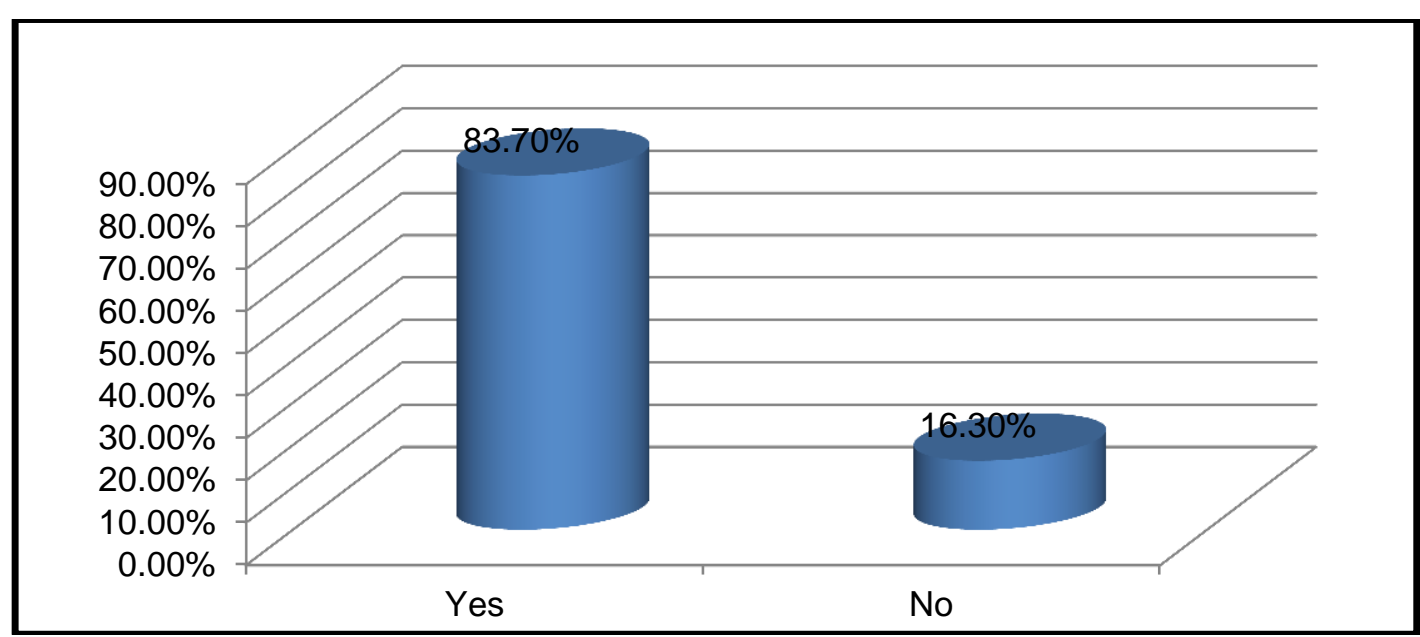

Fig. 4: Field survey showing respondents' awareness of the renovation (gentrification) plan of the Lagos State Government

Source: Authors' Computation, 2018

From Fig. 5, it is evident that almost half of the sample population $48.2 \%$ have been living in Makoko in the last 10 years spanning from 2007 - 2017. Many of them would have migrated into Lagos State in search of the "elusive better life" in a new democratic dispensation, thereby adding to the population of the over-stretched slum community.

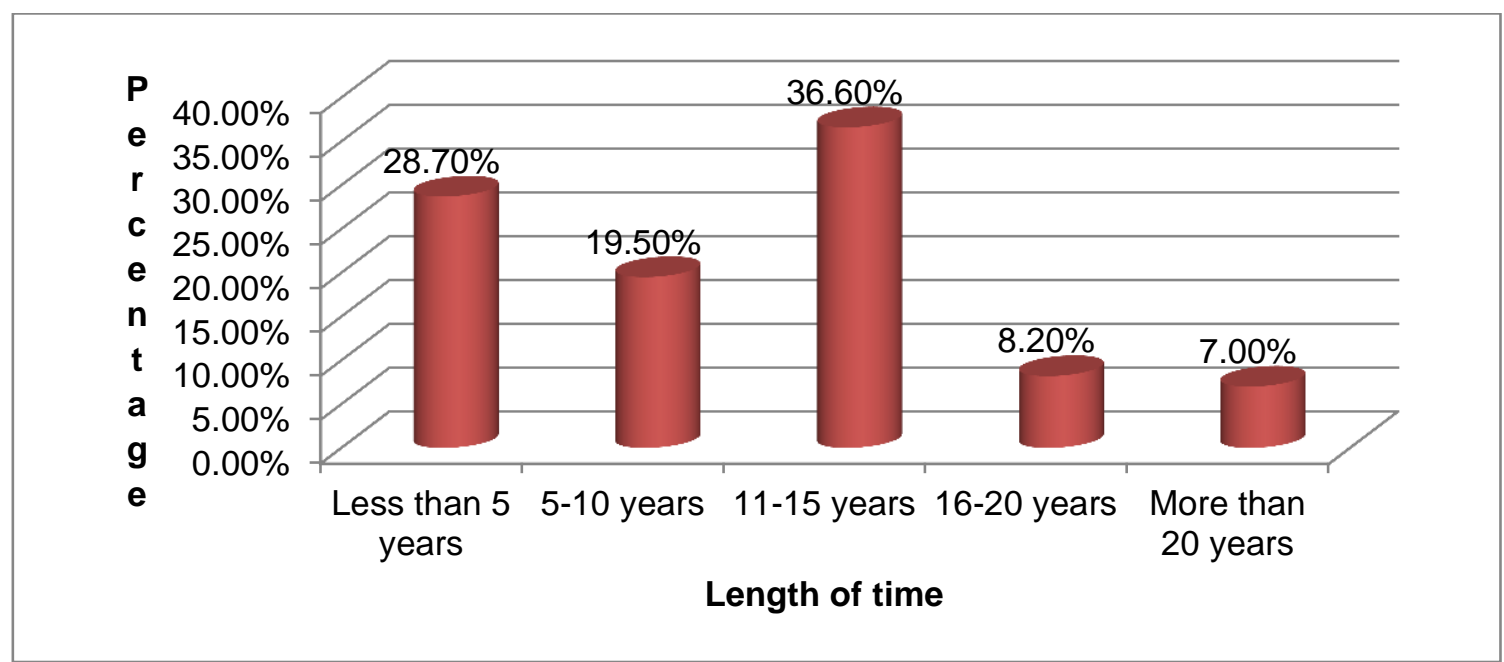

Fig. 5: Field survey showing how long respondents had lived in Makoko Source: Authors' Computation, 2018

In Fig. 6, the responses of an overwhelming $94.9 \%$ of respondents show that majority of Makoko dwellers prefer to stay there, primarily because of their limited means and capacity. This simply implies that urban poverty is a major socio-economic indicator in the neighbourhood. 


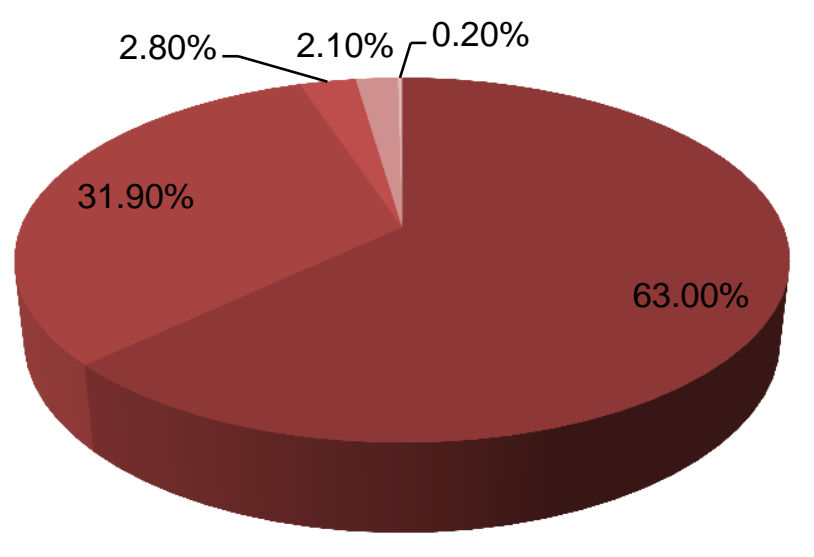

- Cheap accommodation

- Cheap lifestyle

- Nearness to the Lagoon

$\square$ Closeness to my workplace

-Other

Fig. 6: Field survey showing what the respondents liked in Makoko

Source: Authors' Computation, 2018

\section{Validation of research propositions}

Three main issues shaped the research propositions for this study. Consequently, three research propositions were formulated and validated. To validate the propositions, a descriptive analysis of the survey findings from Makoko residents, was employed.

a. Social tensions and pressures: The growth of slums is due to rapid urbanization, migration, rapid population growth lack of job opportunities, which has led to urban tensions creating a situation whereby government and urban elites believe that the presence of slums such as Makoko, increases urban deterioration and fiscal pressures without adding to the economic and social viability of the city (Lees, Shin and López-Morales, 2015; Abrahamson, 2014; UN-Habitat, 20I4; Folarin, 20I0; Morka, 2007; Fallavier, 2003; Mabogunje, 1968).

b. Gentrification: Despite global challenges to gentrification, the goal of Gentrification is embedded in the main paradigm to development policy and practice in Nigeria and in Lagos state. The paradigm focuses on improvements for beautification and fiscal purposes and favour the rich rather than the poor (Lees, Shin and López-Morales, 2015; Kardes, Ozturk, Cavusgil and Cavusgil, 2013; Lees, 2008; Lees, Slater and Wyly, 2008; Logan and Molotch 2007; Freeman and Braconi, 2004).

c. Rights Based Approach to Development: This approach argues that the poor are rational and make calculated choices designed to enhance their access to economic opportunities, thus they remain in the slums, despite its debilitating poverty for reasons of social and economic choice. While the poor live insecure and vulnerable lives due to government sanctions, they do believe they should have a right to security of housing, of tenure and protection from encroachment as well as right to basic services. They are not ignorant as many assume, but aware of the government policies and how it might impact them (United Nations, 2015; International Human Rights Network, 2008; OHCHR, 2006; Landman, 2006; Frankovits, 2005; Appleyard, 2002).

\section{Discussion of findings \\ Research proposition I}

The first proposition states that "the Lagos State government's policy of development is oriented toward beautification and gentrification, rather than the welfare of slum dwellers." This assertion is validated through facts gathered from field survey. The research findings clearly indicate the policy orientation of the Lagos State Government. For instance, on 9th October, 2016, the Lagos State government announced Government's intention to demolish all waterfront informal settlements within 7 days and this proclamation led to the forcible eviction of residents and demolition of residences in several informal communities within Lagos State, including Otodo Gbame, Oworonsoki, Bariga and Iwaya. In addition, existing evidence as seen in the 12 th July, 2012 eviction notice served by the Lagos State government to Makoko residents stated that the Lagos State government was desirous of beautifying the Lagos waterfront/coastline to underline the mega city status of Lagos State and has decided to clear all illegal and unauthorized developments on its waterfront and water bodies. The planning processes of these mega projects are often shrouded in secrecy and they often result into gated neighbourhoods, fenced and guarded, accessible only by authorized people and representing the opposite of an open city. In sharp contrast, urban slums like Makoko are often excluded from basic infrastructure, targeted incentives, subsidies and urban development schemes, as the mega city vision rather goes to the 
concerns of urban elites in Lagos State. The data from field survey further confirms the disposition of the Lagos State government towards the precarious situation of Makoko slum dwellers.

The field survey shows that high population, poor housing, lack of security of life and property, constant outbreak of disease, environmental hazards, poverty, hideout for hoodlums and deviants, lack of basic infrastructure, harassment and social exclusion, among others were identified socio-economic challenges bedevilling Makoko community. The field survey conducted, and the analysis of primary documentation as previously discussed, together establish the fact that policymakers in Lagos state regard informal settlements like Makoko as a drain on the economic and social viability of the state. Makoko slum is depicted by the government as an eyesore in an emerging mega city like Lagos. It is a settlement where most inhabitants live in unhygienic and blighted conditions (Hoelzel, 2016, Chapman and Maki; 2016; Nwanna, 2012; Folarin, 20l0; Morka, 2007). Rather than undertake responsibility for the welfare of residents of these settlements, the government's strategy for state development is to eliminate informal settlements entirely and focus on beautification and gentrification of those areas.

\section{Research proposition II}

The second research proposition states that "the existing development policies in Lagos State will intensify the socio-economic insecurity of current Makoko settlers and worsen social inequalities in the State." Both the field survey and primary documentations provided for this study validate this assertion as a majority of the respondents (93.04\%) opine that if the "renovation" plan of the Lagos State government is allowed to happen, it would lead to displacement, homelessness and loss of means of livelihood.

The field survey showing the reason people prefer to live in Makoko further confirms the likely intensification of the socio-economic insecurity of current Makoko inhabitants. Furthermore, the data on the reason for living in Makoko shows that a majority (88.8\%) of the people living in Makoko live there mainly for socio-economic reasons, including a stark realization that they have no viable alternative for survival. Just over II\% of respondents indicated that they were socially attached to Makoko (described as loving the place) or had other reasons for residing in Makoko. This finding confirms that there is an alarming lack of provision of decent and affordable housing in Lagos State, a State with a population growth of about $7 \%$ per annum and accounts for about 10\% of the housing deficit in Nigeria (National Population Commission, 2016;
Population Reference Bureau, 2016). Apart from the housing deficit, Makoko residents have a rational calculation of their overall options for survival.

Consequently, they consider issues such as proximity to their workplace, the availability of a customer base for their petty trades and fishing occupation and the overall social or community support available while making the decision to remain in Makoko. These are issues that governments often fail to take into cognizance on the rare occasions when they choose to provide alternative isolated low-cost housing projects for people from informal settlements such as Makoko. The research findings indicate clearly that the loss of the integrated socioeconomic system is germane to the survival of residents of urban slums, particularly when they have been evicted without housing alternatives which has caused immense problems, including deepening impoverishment, and increased vagrancy and crime rates. Homelessness has increased the vulnerability of those evicted, particularly of women and children. Rather than resolving the problem, the Lagos state government's approach to development by eviction only worsens the social divides in the state.

\section{Research proposition III}

The third research proposition states that "despite official declarations of the merits of renovating the settlement, Makoko residents are likely to have negative responses to gentrification and to oppose the government's plans for renovations of the Makoko settlement." This assertion was investigated through a number of indicators that attempted to ascertain the overall attitude of Makoko residents to the government's plans for renovation, beautification and gentrification. The study also attempted to determine the rationale for the responses from survey respondents and in particular, to investigate whether these were based on full awareness of the issues at stake, the options facing them and the end goals of the renovations. In the course of validating this proposition, an effort was also made to determine how widely the responses to gentrification were shared by most respondents for instance, of the duration of their residence in Makoko.

The proposition was validated by several important survey findings. First, as seen in the chart above, (83.7\%) of Makoko residents have a meaningful and coherent awareness and understanding of the government's renovation (gentrification) plan.

This awareness is consolidated by the fact that the vast majority of Makoko residents (71.3\%) have lived in the community for well over 5 years, with some having been in residence for over 20 years. Consequently, they have clearly developed strong 
connections and networks in the settlement and stay constantly abreast of the news and policies affecting their community.

As also indicated in the previous analysis of the second proposition, well over $88 \%$ of residents made it clear they were choosing to stay in the settlement for socio-economic reasons in spite of the deleterious environmental, housing and health conditions. It was important to investigate their reasons for staying in Makoko in order to establish the nuances in their responses to government plans for renovating the settlement.

With lucid articulation of their reasons for staying in the Makoko settlement, it is important to note that respondents are not necessarily opposed to moving if they were offered a better option. Indeed, as the field survey indicates, almost $90 \%$ of residents would move out of Makoko if the government was offering them a better alternative.

Makoko residents would therefore clearly only resist the "development" or "renovation" of Makoko if they believed the policy was not about renovation or development, but about gentrification. That is, Makoko residents would welcome improvements in their own living standards (since the data shows they are rational and committed to securing their own best socio-economic options). By the same logic, they would oppose renovations that lead to gentrification, where a higher income population is made to benefit from the renovations and where they, as the original occupants, are displaced as a result of such changes.

It is important to emphasize that the respondents are not opposed to policies that improve their wellbeing as long as they are guaranteed rights of occupancy and the right to remain. The strident and passionate opposition from the residents is because they understand that the end goal is not their own wellbeing as low-income occupants of Makoko. They believe the ultimate goal is gentrification and not beautification, which will ultimately lead to their displacement and provide those developments and improvements for a higher socio-economic population.

As the Rights-Based Approach to Development indicates, although residents of Makoko are regarded as an indigent population, they are clearly very rational and have made calculated choices in order to ensure their continued access to the limited economic opportunities available to them. They have carefully considered their options. Nevertheless, they also make it clear that they are aware they are living insecure and vulnerable lives due to government sanctions, and that they believe they should have a right to human security and basic services. Indeed, a considerable number of respondents as gleaned from the field survey, insist that they would utterly refuse to move if the government attempted to forcibly eject them from the community. While other respondents indicated a state of despair of not even knowing what to do or opting for other strategies for dealing with the threat of forcible ejection. These disturbing results confirm scholarly opinions that forced removals negatively impact the urban poor and it is imperative to make sure that their rights to live within the city and development are institutionalized in Lagos State and Nigeria at large (Hoelzel, 2016; Lees, Shin and López-Morales, 2015; Nwanna, 2012; Folarin, 2010; Morka, 2007).

\section{Limitation of the study}

This study is limited to Makoko area of Lagos State. Also, the study employed a sample size of 1000 respondents. This may not have been representative enough, but it helped to reduce sampling errors and made it possible for the study to investigate the relationship between the variables. During the process of data collection for the study, some respondents had difficulty in filling the questionnaire properly. However, this challenge was overcome through lucid explanations and interpretations by the researcher and his research assistants.

\section{Conclusion}

Consequently, taken collectively, the validation of these research propositions points to the failure of urban renovation and development schemes that view displacement as a means of 'development' and improvement in the society. They also point to the importance of a rights-based approach whereby, the Lagos State government in this case, needs to have the right policies in place that protect the rights to occupancy of current and long-term Makoko residents before embarking on renovations and other improvements of the settlement. This will help to develop an inclusive open city; a city where people will not only have options, but choices and such responses will help deal with locally existing challenges and gaps in urban slums like Makoko.

Furthermore, in the pursuit of social justice and development, the Lagos State Government must consider the fact that the equitable distribution of land and rights to own land is essential for social inclusion, which will eventually lead to an overall improvement in the quality of life in the State. Aransiola and Zarowsky (2014) assert that it is germane to ensure that vulnerable groups like those living in Makoko have free or affordable access to legal services in order to protect them from incessant harassments. It is worthy to note that when the 
urban poor are evicted from their "primordial" neighbourhoods and their residences are demolished for gentrification purposes, it further impoverishes them into a lower quality of life.

It is imperative for the Lagos State Government to realize that in as much as there are the 'push' factors (poverty, low life, etc.) in the rural areas and other parts of the country, people will continue to respond to the 'pull' factors (prosperity, high life, etc.) that Lagos State offers. As such, many of these migrants are likely to move towards low-income neighbourhoods such as Makoko (Ajayi, SoyinkaAirewele and Samuel, 2019). As also noted by Akinyemi and Isiugo-Abanihe (2014) much of Nigeria's development issues are directly or indirectly attributed to the country's rapid population growth and lack of effective governance intensifies the country's growth challenges.

\section{Acknowledgements}

The authors wish to acknowledge the management of Covenant University for funding this research.

\section{References}

Abrahamson, M. (20I4) Urban sociology: A global introduction. New York, United States: Cambridge University Press.

Ajayi, O. (2019) Urban slums, gentrification and the challenge of development: A study of Makoko area of Lagos State, Nigeria (Unpublished doctoral thesis). Covenant University, Ota, Nigeria.

Ajayi, O., Soyinka-Airewele, P., and Samuel, O. (2019) 'Gentrification and the Challenge of Development in Makoko, Lagos State, Nigeria: A Rights-Based Perspective', Environmental Justice, I2(2), pp. 4I-47.

Akinyemi, A. and Isiugo-Abanihe, U.C. (20/4) 'Demographic dynamics and development in Nigeria: Issues and perspectives', African Population Studies, 27(2), pp. 239-248.

Appleyard, S. (2002) A rights-based approach to development: what the policy documents of the United Nations, development cooperation and non-government organizations say (Office of the United Nations High Commisioner for Human Rights document). Geneva, Switzerland: OHCHR.

Aransiola, J. and Zarowsky, C. (20/4) 'Street children, human trafficking and human security in Nigeria: competing discourses of vulnerability and danger', African Population Studies, 27(2), pp. 398-4I0.

Bhattacherjee, A. (20/2) Social science research: Principles, methods and practices. Florida, United States: University of South Florida.

Chapman, M., and Maki, A. (2016) 'Lagos' informal settlements as learning centres for innovation, resilience and inclusion: Community-led solutions to citywide challenges', in Umunna, $M$. and Disu, O. (eds.) Open city Lagos. Abuja, Nigeria: Heinrich Böll Stiftung, pp. I29-I 34.

Cornwall, A. and Nyamu-Musembi, C. (2004) 'Putting the "rights-based approach" to development into perspective', Third World Quarterly, 25(8), pp. |4I5-|437.

Darrow, M., and Tomas, A. (2005) 'Power, capture, and conflict: A call for human rights accountability in development cooperation', Human Rights Quarterly, 27(2), pp. 47I-538.

Falayi, K. (2017) Grim fate for urban poor Lagos communities where residents may lose their homes. Available at: https://punchng.com/grimfate-for-urban-poor-lagos-communities-whereresidents-may-lose-their-homes/ (Accessed: April 29 2018).

Fallavier, P. (2003) Urban slums report: The case of Phnom Penh, Cambodia. London, United Kingdom: Earthscan.

Folarin, S. (2010) 'The Spatial Economy of Abjection: The Evacuation of Maroko Slum in Nigeria', in Adebanwi, W. and Obadare, E. (eds.), Encountering the Nigerian State. New York, NY: Palgrave Macmillan, pp. 55-78.

Frankovits, A. (2005) The human rights-based approach and the United Nations system. Paris, France: UNESCO.

Freeman, L. and Braconi, F. (2004) 'Gentrification and displacement: New York city in the 1990s', Journal of the American Planning Association, 70(I), pp. 39-40.

Fung, A. (2015) 'Putting the public back into governance: The challenges of citizen participation and its future', Public Administration Review, 20(20), pp. I-I0.

Hoelzel, F. (2016) 'Rethinking governance to bring about the "Good City": The case of Lagos', in Umunna, M. and Disu, O. (eds.), Open city Lagos. Abuja, Nigeria: Heinrich Böll Stiftung, pp. 3-I I.

International Human Rights Network (2008) Human rights-based approaches and European Union development aid policies (International Human Rights Network document). County Meath, Ireland: IHRN.

Landman, T. (2006) Indicators for human rightsbased approaches to development in UNDP programming: A users' guide (United Nations document). New York and Oslo: United Nations Development Programme.

Lees, L. (2008) 'Gentrification and social mixing: Towards an urban renaissance?' Urban Studies, 45(I 2), pp. 2449-2470.

Lees, L., Shin, H. and López-Morales, E. (2015) “Gentrification' - a global urban process?', in Lees, 
L., Shin, H. and López-Morales, E. (eds.), Global gentrifications: uneven development. Britain: Policy Press, pp. I-I8.

Lees, L., Slater, T., and Wyly, E. (2008) Gentrification. New York: Routledge.

Logan, R., and Molotch, L. (2007) Urban fortunes. California: University of California Press.

Mabogunje, A. (1968) Urbanization in Nigeria. London: University of London Press.

Morka, F. (2007) A place to live: A case study of the ljora-Badia community, Lagos, Nigeria. (Global Report on Human Settlements). Nairobi, Kenya: UN-Habitat.

National Population Commission (2016) Nigeria. Available at: https://www.nigeriacrvs.gov.ng/

Nwanna, C. (20/2). 'Gentrification in Lagos State: Challenges and prospects', British Journal of Arts and Social Sciences, 5(2), pp. I63-I 76.

Nwanna, C. (2015) 'Gentrification in Nigeria: the case of two housing estates in Lagos', in Lees, L., Shin, H. and López-Morales, E. (eds.) Global gentrifications: uneven development. Britain: Policy Press, pp. 31 I-327.

Piron, L-H. (2003) Overseas development institutions: Learning from the UK Department for International Development's rights-based approach to development assistance (Overseas Development Institute report). London, United Kingdom.

Population Reference Bureau (2016) 2016 World population data sheet. Washington, D.C: PRB.

Serageldin, I. (1996) Directions in development: Liveable cities for the 2 Ist century. Washington D.C: The World Bank.
Soyinka-Airewele, P. and Edozie, E. (2010) 'Reframing Contemporary Africa: Beyond Global Imaginaries', in Soyinka-Airewele, P. and Kiki Edozie, R. (eds.) Reframing Contemporary Africa: Politics, Culture and Society in the Global Era. Washington DC: Congressional Quarterly Press, Pp. I-I0.

UN-Habitat (2016) Housing at the centre. New York, United States: United Nations.

United Nations (2015). Sustainable cities - why they matter. New York: Department of Public Information, United Nations.

United Nations (2018) The sustainable development goals report. New York: United Nations. https://unstats.un.org/sdgs/files/report/20I8/TheS ustainableDevelopmentGoalsReport2018-EN.pdf

United Nations Development Group (2003) The human rights-based approach to development cooperation towards a common understanding among the United Nations agencies. New York: United Nations.

Weiss, M. A. (200I, October) Productive cities and metropolitan economic strategy. Paper Presented to the United Nations International Forum on Urban Poverty (IFUP). Fourth International Conference, Marrakech, Morocco.

Welman, C., Kruger, F., Mitchell, B. and Huysamen, K. (2005) Research methodology. (3rd ed.). Cape Town: Oxford University Press.

Wheeler, S. (1996) Sustainable Urban Development: A Literature Review and Analysis. Retrieved from https://escholarship.org/uc/item/6mx0nOlx 